\title{
PROČ RAKOVINNÁ BUŇKA NESTÁRNE?
}

\section{Jiř́ Patočka, Zdeněk Hon}

IX: 213-458, 2007

ISSN 1212-4117

Jihočeská univerzita v Českých Budějovicích, Zdravotně sociální fakulta, katedra radiologie a toxikologie

Všechno živé stárne a umírá. Každá buňka se po určitém počtu dělení dělit přestává a zaniká. Jen rakovinná buňka je naprostou výjimkou. Dělí se do nekonečna, nestárne, je ,věčně mladá“. Umírá teprve tehdy, když nádor zahubí svého hostitele. Jak je to možné? $V$ čem tkví tajemství nesmrtelnosti nádorové buňky? Tajemství neomezeného množení nádorových buněk tkví $\mathrm{v}$ aktivitě enzymu zvaného telomeráza. Ve zdravých buňkách není tento enzym prítomen, zato nádorové buňky mají tento enzym v plné pohotovosti. Kde se vzala telomeráza $\mathrm{v}$ nádorových buňkách a k čemu slouží?

Množení buněk (buněčné dělenî) je podmínkou zvětšování objemu živé hmoty a růstu organismu. Obvykle probíhá ve dvou fázích. Nejdříve dojde $\mathrm{k}$ dělení jádra (karyokineze), které zaručuje rovnoměrné rozdělení jaderné hmoty do tzv. dceřinných jader, poté následuje rozdělení mateřské buňky (cytokineze) za vzniku dvou buněk dceřinných. Př̀ každém dělení buňky vytvoři mateřská buňka podle své vlastní dědičné informace i dědičnou informaci pro buňku dceřinnou. Kopie dědičné informace v dceřinné buňce je však vždy při každém dělení o něco kratší. Jakoby došlo k malé chybě a kopírování nebylo dotaženo až do konce. Ten chybějící kousek je vždy z koncovek chromozomu, které bývají označovány jako telomery.

Telomera tvoři koncovou část DNA a tato telomerová DNA je tvořena padesátkrát až sedmdesátkrát se opakujícími sekvencemi šestice bází s vysokým obsahem guaninu. U člověka je tento telomerový motiv tvořen bázemi TTAGGG (kde T je thymin, G guanin a A adenin). Telomery slouží jako „hraniční kameny“, které určují, kde daný chromozom začíná a kde končí. Bez nich by v dědičné informaci zavládl chaos. Buňka se při každém dalším dělení a vytváření nové kopie dědičné informace telomeru o něco zkrátí (Harley et al., 1990). Množící se buňky zkracují telomeru tak dlouho, až její délka klesne na kritickou mez, kdy hrozí, že bude $\mathrm{v}$ roli „hraničního kamene“ snadno přehlédnuta. V té chvíli buňka zastaví další dělení a hyne. Díky tomuto mechanismu má každá buňka zakódován jen omezený počet dělicích cyklů a nemůže proto žít věčně.

Tato zdánlivá nedokonalost je ve skutečnosti důmyslnou pojistkou proti nádorovému bujení. Většina rakovinných buněk, které se najednou zvrhnou a začnou se rychle množit, rychle také zkrátí své telomery na kritickou mez a zahynou. Některé z nich si však najdou způsob, jak mobilizovat enzym telomerázu. Telomeráza je schopna chybějící zkrácenou část telomery rychle dostavět a tím jí zabezpečí neomezený počet buněčných dělení. Pokud telomeráza telomerovou DNA rekonstruuje, rakovinná buňka je „věčně mladá“ a nestárne. To zajišt'uje rakovinné buňce nesmrtelnost (Rhyu, 1995; Holt et al., 1997). Napŕíklad tzv. HeLa buňky, pocházející z rakovinné tkáně Heleny Langeové, se neomezeně množí $\mathrm{v}$ tkáňových kulturách tisíců laboratoří na celém světě a mnohonásobně tak přežívají svou nositelku. Telomeráza je $z$ nějakého nám neznámého důvodu $\mathrm{v}$ rakovinných buňkách velmi aktivní, zatímco její činnost ve zdravých buňkách nelze prokázat. Délka života každé buňky jí byla odměřena v okamžiku zrození podle délky telomer, které zdědila od buňky, jejímž rozdělením vznikla, protože sama své telomery prodloužit nedokáže (Campisi, 1997). Výjimkou jsou pouze buňky zárodečné linie a buňky embryonální, které telomerázu mají.

Protože telomeráza poskytuje rakovinné buňce nesmrtelnost, nabízí se tu možnost ukončení růstu rakovinné buňky tím, že se tento enzym zničí. To však není tak jednoduché. Proteinová složka telomerázy nebyla dosud izolována a o její podstatě máme jen omezené znalosti. Hledají se však chemické substance, které by aktivitu tohoto enzymu zastavily, tzv. inhibitory telomerázy (Incles et al., 2003). Ty by totiž mohly být vhodnými léčivy rakoviny. Najít však 
účinný a selektivní inhibitor telomerázy, který by neměl vedlejší toxické účinky na organismus, není tak jednoduché. Zajímavou a nadějnou látkou tohoto druhu je nedávno objevená sub- stance nazvaná telomestatin (Kim et al., 2002; Shin-ya et al., 2001; Tauchi et al., 2003; Patočka, 2007).

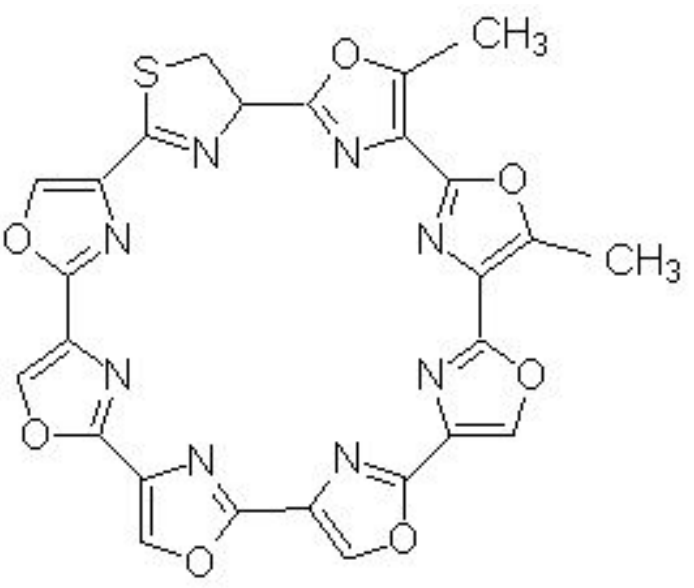

Telomestatin, cyklický poly-oxazol je přírodní inhibitor telomerázy $\left(\mathrm{IC}_{50} \sim 1 \mu \mathrm{M}\right)$ izolovaný $\mathrm{z}$ aktinomycety Streptomyces anulatus 3533-SV4.

Telomestatin byl objeven japonskými vědci jako metabolit aktinomycety Streptomyces anulatus 3533 -SV4 a experimenty potvrdily, že působí velmi selektivně. In vitro je telomestatin schopen zastavovat růst lidských leukemických buněk, ale experimenty $\mathrm{s}$ jeho protirakovinným účinkem zatím neopustily zdi laboratoří. Po chemické stránce představuje telomestatin cyklický polyoxazol, který byl již připraven také $\mathrm{v}$ laboratoři. Chemická struktura látky je dosti neobvyklá a rozhodně velmi zajímavá.

Rovněž vlastní telomeráza může být užitečná jako diagnostický marker pro stanovení stadia onemocnění a také jako prognostický marker vývoje onemocnění. Uvádí se, že zvýšená exprese telomerázy je prokazatelná asi u $90 \%$ maligních nádorů, a proto postup stanovení aktivity telomerázy může významně přispět $\mathrm{k}$ časné detekci nádorového procesu (Hiyama a Hiyama, 2003).

\section{LITERATURA}

CAMPISI, J.: The biology of replicative senescence. Eur J Cancer 1997. Vol. 33, no 5, s. 703-709.

HARLEY, C. B., FUTCHER, A. B., GREIDER, C. W.: Telomeres shorten during ageing of human fibroblasts.
Nature 1990. Vol. 345, no 6274, s. 458-460.

HIYAMA, E., HIYAMA, K.: Telomerase as tumor marker. Cancer Lett 2003. Vol. 194, no 2, s. 221-233.

HOLT, S. E., WRIGHT, W. E.., SHAY, J. W.: Multiple pathways for the regulation of telomerase activity. Eur $\mathrm{J}$ Cancer 1997. Vol. 33, no 5, s. 761-766.

INCLES, C. M., SCHULTES, C. M., NEIDLE, S.: Telomerase inhibitors in cancer therapy: current status and future directions. Curr Opin Investig Drugs. 2003. Vol. 4, no 6, s. 675-685.

KIM, M. Y. et al.: Telomestatin, a potent telomerase inhibitor that interacts quite specifically with the human telomeric intramolecular g-quadruplex. J Am Chem Soc. 2002. Vol. 124, no 10, s. 2098-2099.

PATOČKA, J.: Telomestatin - nový př́stup $\mathrm{v}$ terapii rakoviny. Server TOXICOLOGY https:// toxicology.emtrading.cz/modules.php?name=News\&file $=$ article \&sid $=132 \&$ mode $=$ nocomments\&order $=0 \&$ thold $=1$ RHYU, M. S.: Telomeres, telomerase, and immortality. J Natl Cancer Inst. 1995. Vol. 87, no 12, s. 884-894.

SHIN-YA, K. et al.: Telomestatin, a novel telomerase inhibitor from Streptomyces anulatus. J Am Chem Soc. 2001. Vol. 123, no 6, s. 1262-1263.

TAUCHI, T. et al.: Activity of a novel G-quadruplexinteractive telomerase inhibitor, telomestatin (SOT-095), against human leukemia cells: involvement of ATMdependent DNA damage response pathways. Oncogene. 2003. Vol. 22, no 34, s. 5338-5347. prof.patocka@gmail.com 